\title{
FORUM
}

\section{MAXIMUM DISCLOSURE WITH MINIMUM DELAY}

In his treatment of the subject 'Die SA Weermag moet ook sy ander wapens effektief aanwend' in $7 / 1$ issue of Militaria Colonel W. Otto regards it as incumbent on the South African Defence Force to make effective use of propaganda (in my book the corruption of the channels of communication).

The South African Defence Force should, in the interest of the country, like the Head of State always remain above controversy. For South African Defence Force personnel to get involved with the dissemination of propaganda would, when found out, rob the South African Defence Force of this status, to the detriment of the country.

Propaganda disseminated internally, in support of any objective, could at best only be tolerated as a temporary expedient in our open society, where, fortunately, there could never be a discrepancy between words and reality for long.

In our present situation we really need something far better than propaganda to counter enemy propaganda, and to motivate the public at the same time. This weapon, if one may call it that, is information; credible, complete and timely information co-ordinated at the highest possible level. It is important that the government of the day must be seen and heard to be speaking with one voice.

The only way this could be achieved, I think, is to have a State Information Executive (SIE) with its mission: maximum disclosure with minimum delay, consistent with national security. Such an executive could function as an adjunct to the Office of the Prime Minister or to the Cabinet. (With the constitutional developments in the offing, one could even think of such a body as an adjunct to the Office of the State President or to the Cabinets' Council.)

There is, however, merit in a type of Special Operations Executive (SOE), like existed in World War II, which could work with friendly or resistance elements inside hostile countries to sabotage and subvert the political, economic and military set-ups of these countries. Only, like in the Second World War, it should not be associated with the civil service or the military. Officers with an aptitude for Special Operations Executive work, and there may be a few, could, however, be seconded for service with such an autonomous body.

Psychological operations conducted by the psychological operations personnel of a force, and confined to an area of operations, are also perfectly justified.

Both Special Operations Executive type and psychological operations may of course employ propaganda techniques, and perhaps get away with it too.

Maj J. van R. du Preez

\section{NEW HISTORICAL MATERIALS AT THE IMPERIAL WAR MUSEUM}

The Imperial War Museum in Lambeth, London, UK has made an announcement recently which may be of interest to South African military historians. In July this year the Imperial War Museum's collection of oral history and other sound archive recordings, comprising some 3500 hours of material, were opened to public access. This archive consists of two main sources: recordings made by broadcasting organisations; and the recorded reminiscences of various civilian and service groups. Two major groups of recordings are now organised for public use. The first of these consists of broadcasts obtained from the BBC, and covers the Second World War. The second group comprises interviews recorded by the Museum's staff and broadly covers the period of the First World War dealing with the experiences of the men and women personally involved in the following areas of activity: military and naval aviation; life and operations on the Western Front; life on the lower deck of the Royal Navy, 1910-1922; the anti-war movement; war work. Most of these interviews have also been transcribed and are available in typescript as well as in audio format.

Other groups of material are also available, though in a less organised form, principally 
the interviews recorded for the broadcasting companies for The Great War, The Life and Times of Lord Moumtbatten and The World at War. On the inter-war period too the Museum has undertaken a further recording programme covering such topics as the Spanish civil war and the mechanisation of the British Army. There are also recordings of war artists and poets, sound effects, lectures, speeches and service broadcasts.

Listening and reading facilities are provided for visitors to the Museum, but copies of the recordings and transcripts in which the Museum holds copyright may also be purchased by the public and other material will be available for circulation outside the Museum under the conditions laid down by the appropriate copyright holders.

Any enquiries should be addressed to the Department of Sound Records, Imperial War Museum, Lambeth Road, London SE1, $6 \mathrm{HZ}$, England.

Richard Cornwell. 